$\left.\begin{array}{c}\text { Sournals } \\ \text { INTERNATIONAL JOURNAL OF } \\ \text { ORGANIZATIONAL LEADERSHIP }\end{array}\right) \begin{gathered}\text { INDUSTRIAL } \\ \text { MANAGEMENT } \\ \text { INSTITUTE }\end{gathered}$

\title{
Profiling innovation research in social sciences citation index (2009 to 2014)
}

\author{
Ömür Yaşar Saatçioğlu*, Didem Özer Çaylan, Emir Ozeren \\ Dokuz Eylul University, Izmir, Turkey
}

\begin{abstract}
Keywords:

Innovation Research, CoWord Analysis, BibExcel, Citation, Bibliometric Analysis

Received

30 December 2015

Received in revised form 6 January 2016

Accepted

11 February 2016

Correspondence:

yasar.saatci@deu.edu.tr

Innovation is an important concept for human being that is one of the unavoidable requirements that statuses can transfer to knowledge economy; hence, it affects all nations. The everlasting change also has an effect on the way innovation is performed. In addition, innovation research has some common and basic properties; however, inevitable changes in innovation activities have changed innovation based researches. This reality has made it imperative to undertake research about the change in innovation research. Innovation research encompasses all disciplines and industries. This paper studies the innovation trend in business discipline. To this end, the relevant literature in business discipline published in Social Sciences Citation Index (SSCI) journals from 2009 to 2014 has been reviewed through bibliometric analysis. It has been found that innovation research in business discipline began with the issues related to economy. In addition, much of the research is related to the management function of business. The other noteworthy finding is that innovation is not limited to the boundary of a firm. Instead, firms are innovating with partners. Hence, it becomes a necessity to learn and manage knowledge.
\end{abstract}

(C)AIMI Journals

\section{Introduction}

Nowadays, the global marketplace is characterized by profound social, economic, and technological changes. Consequently, innovation plays a key role in economic development, enhancing and sustaining high performance of firms, building industrial and firm competitiveness, improving the standard of living, and creating a better quality of life. Innovation is, indeed, not a new phenomenon; it is as old as mankind itself. Despite its importance, innovation has not always gained the scholarly attention it deserves. However, this is now rapidly changing. Research on the role of innovation on economic and social change has 
increased in recent years, especially within the social sciences and often with a bent towards being cross-disciplinarily.

Most of the studies on the business and management field focus on its definition and nature rather than its influential application in industries. However, some research should also be performed to evaluate the trend of innovation to provide information about its starting point and ongoing development. This paper includes content analysis of references in the innovation field and formulates groups pertaining to the important topics through scrutinizing the researches carried out in the last five years (between 2009-2014) and represents the most-used key terms in innovation studies, visually and quantitatively, using the bibliometrics analysis method with the help of Web of Science, BibExcel, and Pajek software programs.

The paper aims to answer a number of questions about innovation research over the last five years (from 2009-2014) as follows:

1. What is the overall structure of the innovation field?

2. Do keyword analysis and co-word analysis supply complementary information?

\section{Methodology}

Research evaluation is growingly making broad use of bibliometric data and analyses. Bibliometrics is the analysis of data derived from publications and their citations. Publication of research outcomes refers to an essential part of the research process and is considered as a universal activity. Consequently, bibliometric data have a currency across subjects, time, and location that are found in few other sources of research-relevant data. The use of bibliometric analysis associated with expert review expands the objectivity and confidence in evaluation. Research publications acquire citation counts when they are referred to by more recent publications. Citations to prior work can be regarded as a typical part of publication and represents the value placed in works by later researchers. Some papers are cited frequently and many remain uncited.

In this study, bibliometric analyses, mainly journal citation, citation, word (key term), and co-word analysis are selected as the research techniques. The results of the bibliometric analyses in this article are examined based on the ranking of the most frequently cited journal, citation, and word (key term) analysis, and the evaluation of key terms by mapping the co-word analysis.

Bibexcel software (Persson, Danell, \& Schneider, 2009) is used as the research tool which was developed with the purpose of analyzing bibliometric data (Persson et al., 2009; Al, Sezen, \& Soydal, 2012; Karataş Çetin \& Özer Çaylan, 2015), and mapping is conducted using the Pajek program (Batagelj \& Mrvar, 2003) which is used for the purpose of analyzing and visualizing the widespread networks which are compatible with the files produced by this software. The 1484 researches under analysis in Bibexcel are first brought together in 3 separate groups (0-500 papers, 501-1000 papers, and 1000-1484 papers) as "plain text" in the Web of Science database. Three analyze-ready -.doc extension files are subsequently created in the software. Finally, the papers in three groups are again brought together in the software and converted into one single -.doc extended file. All analyses are performed with the -.doc extended file with 1484 papers compatible with the Bibexcel program. 


\section{The Most Frequently Cited Journals}

The 1484 papers published from 2009 to 2014 are analyzed with "cited journal" criterion in the BibExcel program. As a result, the first 20 journals with the highest frequency are identified in Table 1.

Table 1

The Most Frequently Journals, 2009-2014

\begin{tabular}{|c|c|c|c|c|}
\hline Ranking & Cited Journals & Impact Factors $(2013 *)$ & \# of Citations & $\%$ in Total Citations \\
\hline 1 & Strategic Management Journal & 2.993 & 4016 & 6.34 \\
\hline 2 & Research Policy & 2.598 & 3143 & 4.96 \\
\hline 3 & Academy of Management Journal & 4.974 & 2406 & 3.80 \\
\hline 4 & Journal of Product Innovation Management & 1.379 & 2304 & 3.64 \\
\hline 5 & Journal of Marketing & 8.819 & 2261 & 3.57 \\
\hline 6 & Academy of Management Review & 7.817 & 1929 & 3.05 \\
\hline 7 & Administrative Science Quarterly & 2.394 & 1743 & 2.75 \\
\hline 8 & Organizational Science & 3.807 & 1728 & 2.73 \\
\hline 9 & Management Science & 2.524 & 1581 & 2.50 \\
\hline 10 & Journal of Marketing Research & 2.660 & 1151 & 1.82 \\
\hline 11 & Harvard Business Review & 1.831 & 1081 & 1.71 \\
\hline 12 & Technovation & 2.704 & 862 & 1.36 \\
\hline 13 & R\&D Management & 1.266 & 842 & 1.33 \\
\hline 14 & Journal of Management & 6.862 & 818 & 1.29 \\
\hline 15 & Industrial Marketing Management & 1.897 & 816 & 1.29 \\
\hline 16 & Journal of Business Research & 1.306 & 815 & 1.29 \\
\hline 17 & Journal of Management Studies & 3.277 & 659 & 1.04 \\
\hline 18 & Journal of International Business Studies & 3.594 & 633 & 1.00 \\
\hline 19 & California Management Review & 1.944 & 606 & 0.96 \\
\hline \multirow[t]{3}{*}{20} & Journal of The Academy of Marketing Science & 3.410 & 600 & 0.95 \\
\hline & Other Journals Cited & & 33.325 & 52.63 \\
\hline & Total Citations to Journal Articles & & 63.319 & \\
\hline
\end{tabular}

*Source: Thomson Reuters, ISI Web of Science 2015 Citation Report

\section{Citation Analysis}

In the 5-year period for citation analysis, a total of 1484 researches are examined and the first 25 researches are listed as those most frequently cited which were extracted from the Bib Excel program according to the "cited document (CD)" criterion as shown in Table 2. The citation analysis was limited to references with a frequency greater than seventy $(\mathrm{Fq}>70)$.

\section{Co-Word Analysis}

Co-word analysis refers to a content analysis technique that is practical and successful in mapping the power and influence of association between keywords in textual data. Co-word analysis decreases the space of descriptors (or keywords) to a set of network graphs that adequately explains and exhibits the strongest associations between descriptors (Whittaker, 1989; Coulter, Monarch, \& Konda, 1998; Muñoz-Leiva, Viedma-del-Jesús, SánchezFernández, \& López-Herrera, 2012). Co-word analysis utilizes the patterns of co-occurrence of 
pairs of items such as words or noun phrases in a corpus of texts to classify the relationships between ideas within the subject areas presented in these texts (He, 1999). Words which are used very frequently and which are, indeed, used almost systematically in the indexation of the documents in the file being studied will be at an advantage with respect to words used less often (Callon, Courtial, \& Laville, 1991). Therefore, the words are important in this analysis and can be extracted from titles, abstracts, full texts, or keyword lists of various types of scientific publications. The main purpose of this co-word technique is to show the dynamics of the scientific field's development by visually representing the co-occurrence matrix of words chosen according to their frequency in the corpus. Higher co-occurrence frequency of two key words demonstrates closer and stronger links between them. The closer links between two keywords represent closer relationships between the concepts they refer to (Bosanac, Matešić, \& Tolić, 2009).

Table 2

Citation Analysis of 1484 Researches in Web of Science including the Term "Innovation" in their Titles from 2009-2014 in Management and Business Journals (Frequencies $=$ and >70)

\begin{tabular}{|c|c|c|c|c|}
\hline Number & \multicolumn{2}{|c|}{ Labels of the Top 25 Cited References } & Type & Frequency \\
\hline 1 & Cohen and Levinthal (1990) & Administrative Science Quarterly & Research Article & 232 \\
\hline 2 & $\operatorname{March}(1991)$ & Organizational Science & Research Article & 147 \\
\hline 3 & Barney (1991) & Journal of Management & Research Article & 144 \\
\hline 4 & Chesbrough (2003) & $\begin{array}{l}\text { Open innovation: The new imperative for } \\
\text { creating and profiting from technology }\end{array}$ & Book & 144 \\
\hline 5 & Nelson and Winter (1982) & An Evolutionary Theory of Economic Change & Book & 143 \\
\hline 6 & Fornell \& Larcker (1981) & Journal of Marketing Research & Research Article & 130 \\
\hline 7 & Teece, Pisano, and Shuen (1997) & Strategic Management Journal & Research Article & 120 \\
\hline 8 & Eisenhardt (1989) & Academy of Management Review & Research Article & 118 \\
\hline 9 & $\begin{array}{l}\text { Podsakoff, MacKeniz, Lee, and } \\
\text { Podsakoff (2003) }\end{array}$ & Journal of Applied Psychology & Research Article & 103 \\
\hline 10 & Damanpour (1991) & Academy of Management Journal & Research Article & 101 \\
\hline 11 & Laursen and Salter (2006) & Strategic Management Journal & Research Article & 98 \\
\hline 12 & Schumpeter and Redverse (1983) & $\begin{array}{c}\text { The theory of economic development: An } \\
\text { inquiry into profits, capital, credit, interest, and } \\
\text { the business cycle }\end{array}$ & Book & 91 \\
\hline 13 & Teece (1986) & Research Policy & Research Article & 89 \\
\hline 14 & $\begin{array}{l}\text { Powell, Koput, and Smith-Doerr } \\
\text { (1996) }\end{array}$ & Administrative Science Quarterly & Research Article & 86 \\
\hline 15 & Eisenhardt and Martin (2000) & Strategic Management Journal & Research Article & 83 \\
\hline 16 & Kogut and Zander (1992) & Organizational Science & Research Article & 81 \\
\hline 17 & Von Hippel (1988) & The Sources of Innovation & Book & 81 \\
\hline 18 & Aiken and West (1991) & $\begin{array}{l}\text { Multiple regression: Testing and interpreting } \\
\text { interactions }\end{array}$ & Book & 79 \\
\hline 19 & Zahra and George (2002) & Academy of Management Review & Research Article & 76 \\
\hline 20 & Henderson and Clark (1990) & Administrative Science Quarterly & Research Article & 76 \\
\hline 21 & Nonanka and Takeuchi (1995) & $\begin{array}{c}\text { The knowledge-creating company: How } \\
\text { Japanese companies create the dynamics of } \\
\text { innovation }\end{array}$ & Book & 74 \\
\hline 22 & Baron and Kenny (1986) & Journal of Personality and Social Psychology & Research Article & 73 \\
\hline 23 & Levinthal and March (1993) & Strategic Management Journal & Research Article & 71 \\
\hline 24 & Wernerfelt (1984) & Strategic Management Journal & Research Article & 70 \\
\hline 25 & Leonard-Barton (1992) & Strategic Management Journal & Research Article & 70 \\
\hline
\end{tabular}

In order to identify articles of higher quality or impact, 1484 related articles were further analyzed by their citation counts in the Social Sciences Citation Index (SSCI) (as of March 15, 2015). Articles with more citation frequencies are usually those that are better recognized by others in related fields. They apparently illustrate more basic ideas about the issues for future research. The citation counts higher than 70 were selected and explained. From all the researches, there were 6 books and 19 articles which have a citation count of more than 70 . 
As it is shown in Table 1, the most cited journal is Strategic Management Journal which describes strategy related issues. Hence, it can be concluded that innovation is considered as a strategic factor within firms. The second conclusion is that majority of the most cited journals are related to management, marketing, business, and R\&D management. It can be inferred that the most researched business function is management. In Table 2, the top 25 cited research are given. Table 3 shows the categories of innovation research and related references.

Table 3

Categories of Innovation Researches and Related References

\begin{tabular}{|c|c|}
\hline Categories of Innovation Research & References \\
\hline Typology of Innovation & $\begin{array}{l}\text { Organizational Innovation by Damanpour (1991) } \\
\text { Open Innovation by Laursen and Salter (2006) and Chesbrough (2003) } \\
\text { Architectural Innovation by Henderson and Clark (1990) }\end{array}$ \\
\hline $\begin{array}{l}\text { Resources of Firm and Organizational } \\
\text { Performance }\end{array}$ & $\begin{array}{l}\text { Firm Resources and Sustained Competitive Advantage by Barney (1991) } \\
\text { Dynamic Capabilities of Firm and Strategic Management by Teece et al. (1997) } \\
\text { Resource Based View and Strategic Options by Wernerfelt (1984) } \\
\text { Content of Resource Based View by Eisenhardt and Martin (2000) and Leonard-Barton (1992) }\end{array}$ \\
\hline Antecedents of Innovation & $\begin{array}{l}\text { Creation of Firm Knowledge by Kogut and Zander (1992) } \\
\text { Learning Processes and Exploration of New Possibilities and Exploitation of Old Certainties by } \\
\text { March (1991) } \\
\text { Limitations in Learning by Levinthal and March (1993) } \\
\text { Absorptive Capacity as a Link by Knowledge, Learning and Innovation by Cohen and Levinthal } \\
\text { (1990) } \\
\text { Types of Absorptive Capacity by Zahra and George (2002) }\end{array}$ \\
\hline Others & $\begin{array}{l}\text { An Evolutionary Theory of Economic Change by Schumpeter and Redverse (1983) } \\
\text { Organizational Roles, Structure and Practices, Continuous Innovation by Nonaka and Takeuchi } \\
\text { (1995) } \\
\text { Sources of Innovation by Von Hippel (1988) } \\
\text { Innovation Failure by Teece (1986) } \\
\text { Methodological Concepts by Podsakoff et al. (2003); Fornell and Larcker (1981); Baron and Kenny } \\
\text { (1986) }\end{array}$ \\
\hline
\end{tabular}

The first stream of research is about typology of innovations. Three innovation typologies are clearly explained in the cited articles. One of them is organizational innovation by Damanpour (1991), open innovation by Chesbrough (2003), Laursen and Salter (2006), and architectural innovation by Henderson and Clark (1990). Architectural innovations can be defined as innovations that modify the architecture of a good without changing its components. Therefore, product innovation can also be used instead of architectural innovation.

The second stream of research is related to the capabilities of the firm and their effects on organizational performance. Barney (1991) linked firm resources to sustained competitive advantage, and Teece et al. (1997) linked dynamic capabilities of the firm with strategic management. Wernerfelt (1984) explained resource based view and the related strategic options. The content of the resource based view as core capabilities and dynamic capabilities were examined in detail in two articles by Eisenhardt and Martin (2000) and Leonard-Barton (1992). Aramburu and Sáenz (2011) pointed out that innovation is at the core of dynamic capabilities. Innovation and the resources of organization shape each other by means of new knowledge as new products, services, processes, technologies, or business models manifest themselves.

The third stream of research is about the relationship between knowledge, learning, and absorptive capacity. Mainly, the third stream of research can be conceptualized as antecedents of innovation. Kogut and Zander (1992) examined the way in which firms created knowledge. The research also pointed out the importance of social relationships. March (1991) related 
learning processes with the exploration of new possibilities and exploitation of old certainties in organizational learning. Levinthal and March (1993) discussed the limitations in learning. The most cited article in the SSCI database is about absorptive capacity written by Cohen and Levinthal (1990). Absorptive capacity is the capability to identify the usefulness of new information, assimilate it, and apply it to commercial ends. Absorptive capacity has been recognized as an important knowledge-based capability affecting its innovative capabilities of collaborating firms (Newey and Verreynne, 2011). Absorptive capacity simply links knowledge, learning, and innovation. Zahra and George (2002) extended the absorptive capacity concept to a new concept; they divided the absorptive capacity concept into potential and realized capacity. The notion of absorptive capacity is based on the idea that learning is cumulative and what one learns is a function of what one knows. Firms face increasingly dynamic and complex environments and, more than ever, need to properly manage internally and externally acquired knowledge to develop a learning process that will allow rapid and proactive adaptation to changing market needs and consolidate the processes of creation of added value. Lack of information can be considered one of three greatest inhibitors of innovation and Santos-Vijande, López-Sánchez, and Gonzáles-Mieres (2012) stated that it is impossible to innovate without absorptive capacity since innovation depends on accumulated knowledge. The learning process allows knowledge management within the firm and enables employees to properly understand and apply that knowledge in the development of innovations. Innovation is developed from the firm's knowledge base and innovation can be understood as a learning process. Firms that are able to learn stand a better chance of sensing events and trends in the marketplace, and continuous innovation allows them to respond and proactively adapt to increasingly dynamic and complex markets (Santos-Vijande et al., 2012). Learning, knowledge, absorptive capacity, and innovation are separate but related constructs.

Teece's (1986) articles cannot be defined in the above four research streams. Teece discussed why innovating firms often fail to obtain significant economic returns from an innovation while customers, imitators, and industry participants benefit. The other four articles are related to research approaches. Eisenhardt (1989) describes the case study approach which is mostly used in innovation related searches. Podsakoff et al. (2003), Fornell and Larcker (1981), and Baron and Kenny (1986) discussed methodological concepts.

Schumpeter and Redverse (1983) are among the pioneering scholars in innovation research. They emphasize the importance of innovation and technology in economic progress in contrast to the semi-mechanical monetary factors, but it also stresses the role played by credit in economic development. The book "An Evolutionary Theory of Economic Change" is one of the most important contributions to the study of innovation and long running economic and social change. A more elaborate and theoretical perspective on how firms behave is introduced. In the book, social and economic consequences of interaction within populations of heterogeneous actors are examined. The book has been an important source of inspiration for subsequent work on "knowledge-based firms", "technological regimes", and "industrial dynamics" and "evolutionary economics", more generally, to mention some important topics. The book traced its roots to the works of economists such as Schumpeter and Redverse (1983) and Nonaka and Takeuchi (1995) who explained the organizational roles, structures, and practices that produce continuous innovation. The relationship between innovation and 
knowledge creation is established in works by Nonaka (1991) and Nonaka and Takeuchi (1995). Aramburu and Sáenz (2011) pointed out that understanding the sources of successful innovation has become one of the main challenges for academic researchers in the business world. Von Hippel (1988) showed that sources of innovation vary greatly. Sometimes the users, sometimes the suppliers, or sometimes conventional wisdom are the sources of innovation. He explained the reasons for this variation and the way it can be predicted. Chesbrough (2003) introduced the open innovation concept which rejects the boundary of innovation and proposed the actors in the external environment, as important innovation contributors, should be connected with the contributors inside the firm. Nonaka and Takeuchi (1995) highlighted that the mobilization of external knowledge held by outside stakeholders is a crucial aspect to encourage and foster knowledge creation. Aiken and West (1991) criticized the underutilization of multiple regressions and explained the use of procedures. Table 4 presents word analysis of the references and their frequencies.

Table 4

Word (Key Term) Analysis of the References and Their Frequencies (37 Key Terms with Frequency > 10)

\begin{tabular}{|c|c|c|c|}
\hline Frequency & Key Terms & Frequency & Key Terms \\
\hline 372 & Innovation & 16 & Intellectual Property \\
\hline 57 & Open Innovation & 16 & Knowledge \\
\hline 37 & Service Innovation & 16 & Competitive Advantage \\
\hline 36 & Entrepreneurship & 15 & Patents \\
\hline 35 & Product Innovation & 14 & Innovation Policy \\
\hline 28 & Organizational Innovation & 13 & Spain \\
\hline 28 & $R \& D$ & 13 & Process Innovation \\
\hline 27 & Innovation Performance & 13 & Strategy \\
\hline 26 & China & 12 & Sustainability \\
\hline 24 & Radical Innovation & 12 & Business Model \\
\hline 23 & Performance & 12 & Business Model Innovation \\
\hline 23 & SMEs & 11 & Collaboration \\
\hline 20 & Networks & 11 & Taiwan \\
\hline 19 & Market Orientation & 11 & New Product Development \\
\hline 17 & Social Capital & 11 & Organizational Learning \\
\hline 17 & Knowledge Management & 11 & Dynamic Capabilities \\
\hline 17 & Technological Innovation & 11 & Capabilities \\
\hline 17 & Absorptive Capacity & 11 & Learning \\
\hline 17 & Innovation Management & 3086 & Total Number of Key Terms \\
\hline
\end{tabular}

The words in Table 4 are categorized in Table 5 as shown below.

Table 5

Categories of Key Words Used in Innovation Research

\begin{tabular}{|c|c|c|c|}
\hline Typology of Innovation & Resources of Firm & Antecedents and Consequences of Innovation & Others \\
\hline $\begin{array}{c}\text { Innovation } \\
\text { Open Innovation } \\
\text { Service Innovation } \\
\text { Product Innovation } \\
\text { Organizational Innovation } \\
\text { Radical Innovation } \\
\text { Technological Innovation } \\
\text { Process Innovation } \\
\text { Business Model Innovation }\end{array}$ & $\begin{array}{c}\text { Capabilities } \\
\text { Dynamic Capabilities }\end{array}$ & $\begin{array}{c}\text { Knowledge } \\
\text { Knowledge Management } \\
\text { Absorptive Capacity } \\
\text { Innovation Management } \\
\text { Learning } \\
\text { Organizational Learning } \\
\text { Collaboration } \\
\text { Networks }\end{array}$ & SME \\
\hline
\end{tabular}

As seen in Table 4, Table 5, and Figure 1, the most used keyword is "innovation" which is just the main concept. The other most used keywords are mainly about innovation types such as "open innovation", "service innovation", "product innovation", "organizational innovation", "radical innovation", "technological innovation", "process innovation", and "business model 
innovation". The other group of keywords, namely "knowledge", "knowledge management", "absorptive capacity", "innovation management", "learning", "organizational learning", "collaboration", "dynamic capabilities", and "capabilities" are related to the important parameters related to effective innovation management. The other important factor is the SMEs keyword which indicates that much of the researches are related to SMEs. Besides, usage of keywords networks and collaboration and high citation of open innovation indicates that innovation is not closed within the boundaries of firms but occurs in collaboration with partners.

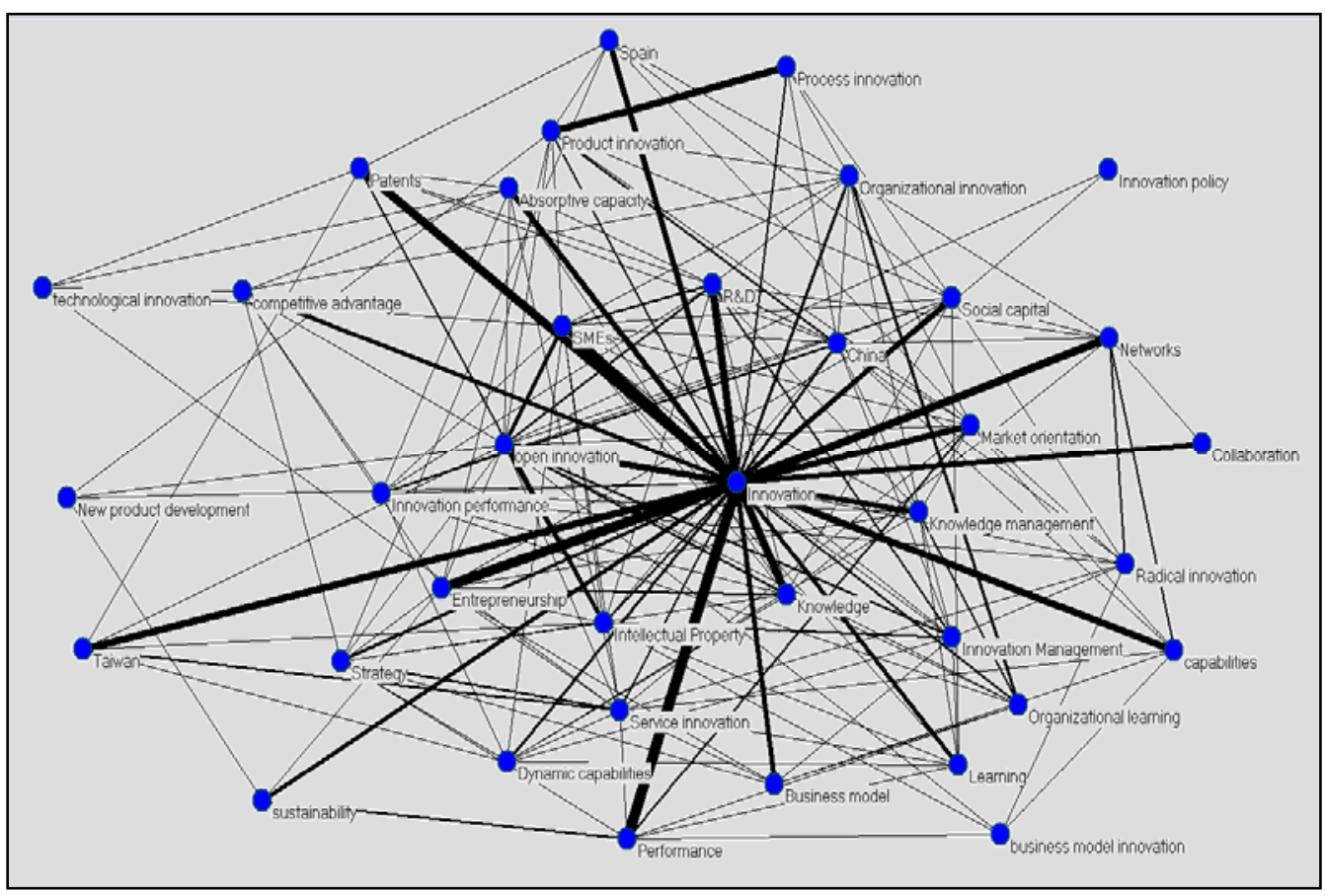

Figure 1. Co-Word Analysis of the Key Terms of 1484 Research Articles (Frequency >10)

Sung, Cho, and Choi (2011) examined innovation based research in two categories: The variance approach which examines a variety of predictors that promote innovation; and process approach which attempts to provide a detailed account of the complex developmental processes underlying an innovation. The research outlined in this paper also shows that the trend in innovation research is related both to the variance approach and the process approach. Figure 1 represents the co-word analysis of the key terms of 1484 research articles.

\section{Conclusion}

Innovation has always been a significant source for competitive advantage in countries, industries, regions, firms, and even individuals. Hence, a systematic examination of innovation trends in the relevant literature is an important issue for scholars from various disciplines. To achieve this, a bibliometric analysis of innovation research in the business and management field published in SSCI journals from 2009 to 2014 was conducted. The current research provided valuable insights about types of innovation and major streams of innovation research and allows formulation of innovation profiles from different viewpoints. 
There are some noteworthy findings derived from citation and keyword analysis. First of all, most of the innovation researches in business are related to management. The other important conclusion is that innovation is no longer held just inside the boundaries of firms. In this regard, the more innovative firms receive a more favorable response from their environment, more easily obtaining the necessary capabilities to improve organizational performance and consolidate their competitive advantages. Competitive pressure has increased the openness of the present innovation era. It is now relying on knowledge from external sources. Furthermore, innovation is now dependent on extensive interaction with the environment. "Systems" and "networks" are used to explain this reality. Knowledge and learning are the main concepts that are necessary to gain maximum benefit from innovation. This is a pioneering study since there has not been any research dealing with research trends regarding innovation. However, the main finding of this research is that the study covers only a five-year period. Further contributions could result in an extended period. Besides, such research should be detailed in different types of content that could realize different innovation types and could be detailed in the business discipline. The research in business discipline could also involve geographic concentrations of innovation and author related information. Some limitations should be addressed. The first one is that the analysis concentrated on priority themes. The second limitation is that the diversity of papers included in the analysis makes it difficult to justify their integration.

\section{References}

Aiken, L. S., \& West, S. G. (1991). Multiple regression: Testing and interpreting interactions. Newbury Park, CA: Sage.

Al, U., Sezen, U., \& Soydal, İ. (2012). Türkiye'nin Bilimsel Yayınlarının Sosyal Ağ Analizi ile Değerlendirilmesi, TUBíTAK Projesi. Ankara: TÜBİTAK.

Aramburu, N., \& Sáenz, J. (2011). Structural capital, innovation capability and size effect: An empirical study. Journal of Management \& Organization, 17(3), 307-325.

Barney, J. (1991). Firm resources and sustained competitive advantage. Journal of Management, 17(1), 99-120.

Baron, R., \& Kenny, D. (1986). The moderator-mediator variable distinction in social psychological research: Conceptual, strategic and statistical considerations. Journal of Personality \& Social Psychology, 51(6), 1173-1182.

Batagelj, V., \& Mrvar, A. (2003). Pajek: Analysis and visualization of large networks. In Junser, M., \& Mutzel, P. (Eds.), Graph drawing software (pp. 77-144). New York: Springer.

Bosanac, S., Matešić, M., \& Tolić, N. (2009). Telling the future of information science: Co-word analysis of keywords in scientific literature produced at the department of information sciences in Zagreb. Proceedings of the 2nd International Conference on the Future of Information Sciences, INFuture2009-Digital Resources and Knowledge Sharing, University of Rijeka, Zagreb, Croatia.

Callon, M., Courtial, J. P., \& Laville, F. (1991). Co-word analysis as a tool for describing the network of interactions between basic and technological research: The case of polymer chemistry. Scientometrics, 22(1), 155-205.

Chesbrough, H. W. (2003). Open innovation: The new imperative for creating and profiting from technology. Boston, MA: Harvard Business School Press. Cohen, W. M., \& Levinthal, D. A. (1990). Absorptive capacity: A new perspective on learning and innovation. Administrative Science Quarterly, 35(1), 128-152.

Cohen, W. M., \& Levinthal, D. A. (1990). Absorptive capacity: A new perspective on learning and innovation. Administrative Science Quarterly, 35(1), 128-152.

Coulter, N., Monarch, I., \& Konda, S. (1998). Software engineering as seen through its research literature: A study in co-word analysis. Journal of the American Society for Information Science (JASIS), 49(13), 1206-1223.

Damanpour, F. (1991). Organizational innovation: A meta-analysis of effects of determinants and moderators. Academy of Management Journal, 34(3), 555-590.

Eisenhardt, K. M. (1989). Building theories from case study research. Academy of Management Review, 14(4), 532-550.

Eisenhardt, M., \& Martin, J. (2000). Dynamic capabilities: What are they? Strategic Management Journal, 21, $1105-1121$. 
Fiol, C. M. (1996). Squeezing harder doesn't always work: Continuing the search for consistency in innovation research. Academy of Management Review, 21(4), 1012-1021.

Fornell, C., \& Larcker, D. F. (1981). Evaluating structural equation models with unobservable variables and measurement error. Journal of Marketing Research, 18, 39-50.

He, Q. (1999). Knowledge discovery through co-word analysis. Library Trends, 48(1), 135-159.

Henderson, R. M., \& Clark, K. B. (1990). Architectural innovation: The reconfiguration of existing product technologies and the failure of established firms. Administrative Science Quarterly, 35(1), 9-30.

Karataş Çetin, Ç., \& Özer Çaylan, D. (2015). Stratejik yönetim yazınının entelektüel yapısında değişim: 2001-2013 yılları arası bibliyometrik bir değerlendirme. Atatürk Üniversitesi İktisadi ve İdari Bilimler Dergisi, 29(1), 101-120.

Kogut, B., \& Zander, U. (1992). Knowledge of the firm, combinative capabilities, and the replication of technology. Organization Science, 3(3), 383-397.

Laursen, K., \& Salter, A. (2006). Open for innovation: The role of openness in explaining innovation performance among UK manufacturing firms. Strategic Management Journal, 27(2), 131-150.

Leonard-Barton, D. (1992). Core capabilities and core rigidities: A paradox in managing new product development, Strategic Management Journal, 13, 111-125.

Levinthal, D. A., \& March, J. G. (1993). The myopia of learning. Strategic Management Journal, 14, 95-112.

March, J. G. (1991). Exploration and exploitation in organizational learning. Organization Science, 2(1), 71-87.

Muñoz-Leiva, F., Viedma-del-Jesús, M. I., Sánchez-Fernández, J., \& López-Herrera, A. G. (2012). An application of co-word analysis and bibliometric maps for detecting the most highlighting themes in the consumer behaviour research from a longitudinal perspective. Quality \& Quantity Journal, 46, 1077-1095.

Nelson, R., \& Winter, S. (1982). An evolutionary theory of economic change. Cambridge, MA: Harvard University Press.

Newey, L., \& Verreynne, M. L. (2011). Multilevel absorptive capacity and interorganizational new product development: A process study. Journal of Management \& Organization, 17(1), 39-55.

Nonaka, I. (1991). The knowledge creating company. Harvard Business Review, 69(6), 96-104.

Nonaka, I., \& Takeuchi, H. (1995). The knowledge creating company: How Japanese companies create the dynamics of innovation. Oxford, UK: Oxford University Press.

Persson, O. D. (2013). BibExcel: A tool-box developed by Olle Persson. Sweden: Inforsk, Umeå Univ.

Persson, O. D., Danell, R., \& Schneider, J. W. (2009). How to use Bibexcel for various types of bibliometric analysis. In F. Åström, R. Danell, B. Larsen, , \& J. Schneider (Eds.), Celebrating scholarly communication studies: A Festschrift for Olle Persson at his 60th Birthday (pp. 9-24). Leuven, Belgium: International Society for Scientometrics and Informetrics.

Podsakoff, P. M. , MacKenzie, S. B., Lee, J. -Y. , \& Podsakoff, N. P. (2003). Common method biases in behavioral research: A critical review of the literature and recommended remedies. Journal of Applied Psychology, 88(5), 879-903.

Powell, W. W., Koput, K. W., \& Smith-Doerr, L. (1996). Interorganizational collaboration and the locus of innovation: Networks of learning in biotechnology. Administrative Science Quarterly, 41(1), 116-145.

Santos-Vijande, M. L., López-Sánchez, J. Á., \& Gonzáles-Mieres, C. (2012). Organizational learning, innovation and performance in KIBS. Journal of Management \& Organization, 18(6), 870-904.

Schumpeter, J. A., \& Redverse, O. (1983). The theory of economic development: An inquiry into profits, capital, credit, interest and the business cycle. New Brunswick, New Jersey: Transaction Books.

Sung, Y. S., Cho, D. S., \& Choi, J. N. (2011). Who initiates and who implements? A multi-stage, multi-agent model of organizational innovation. Journal of Management \& Organization, 17(3), 344-363.

Teece, D. J.(1986). Profiting from technological innovation: Implications for integration, collaboration, licensing and public policy. Research Policy, 15, 285-305.

Teece, D. J., Pisano, G., \& Shuen, A. (1997). Dynamic capabilities and strategic management. Strategic Management Journal, $18(7), 509-533$.

Von Hippel, E. (1988). The sources of innovation. Oxford, UK: Oxford University Press.

Wernerfelt, B. (1984). A resource-based view of the firm. Strategic Management Journal, 5(2), 171-180.

Whittaker, J. (1989). Creativity and conformity in science: Titles, keywords and co-word analysis. Social Studies of Science, 19(3), 473-496.

Zahra, S. A., \& George, G. (2002). Absorptive capacity: A review, reconceptualization and extension. Academy of Management Review, 27(2), 185-203. 